\title{
A complete life cycle perspective on habitat requirements that control species distribution; a case study of Psammechinus miliaris in the Eastern Scheldt, Grevelingen and North Sea
}

\author{
Name \\ Student nr. \\ Course nr. \\ Supervisors \\ Date \\ Research Group
}

\author{
Kees te Velde \\ 930428862090 \\ YBI-85812 \\ Mischa Streekstra and Tinka Murk \\ 26-05-2017 \\ Marine Animal Ecology, Wageningen University and Research
}

\begin{abstract}
The distribution and abundance of an animal is largely dependent on its habitat requirements and these requirements often change throughout its life-cycle. So to know the true impact of (a)biotic factors on a species distribution and abundance, the whole life cycle should be considered. This study aims to illustrate a fast and relatively simple approach to gain knowledge on the importance of certain habitat requirements in controlling species abundance and distribution, by comparing habitat requirements of a species' life stages with the (a)biotic values found in nature. This is illustrated through a detailed case study of the sea urchin species, Psammechinus miliaris. Nine biotic and abiotic factors were studied, namely diet, food quantity, hydrodynamics, oxygen, hydrostatic pressure, salinity, bottom type / substrate, $\mathrm{pH}$ and temperature. For each of these abiotic and biotic factors, the minimum, maximum and average values were determined in the Grevelingen, North Sea and Eastern Scheldt through a literature study. The minimum and maximum habitat requirements for every abiotic and biotic factor where then determined through a literature study for each of the six $P$. miliaris life stages: gametes, embryo, larvae, metamorphosis, juveniles and adults. The literature search was extended by comparing data of $P$. miliaris observations and water temperatures in the Eastern Scheldt and Grevelingen Lake to explore the relationship between the yearly differences in water temperature and $P$. miliaris abundance over a 22 year period. The results show that hydrodynamics, temperature and bottom type are important limiting factors for $P$. miliaris, whilst hydrostatic pressure and salinity are of little to no importance. This study shows that there is a lack of research towards hydrodynamics and bottom type and it provides evidence that seawater temperatures below $1{ }^{\circ} \mathrm{C}$ negatively affect $P$. miliaris populations. This case study illustrates a relatively easy way to get a broad understanding of the habitat requirements of an organism, to identify knowledge gaps in the research area and to prioritise further research efforts.
\end{abstract}




\section{Introduction}

Many livelihoods depend on the abundance and distribution of specific animal and plant species, both directly and indirectly. Directly as food or a source of income. Indirectly, through ecosystem engineers like mangrove trees, that provide habitats to many important fish species and prevent erosion and sediment loss of coastal areas, thereby preventing land-loss and reducing the chance of floods (1). Because of this importance, the collapse of a species population can have huge economic- and societal consequences. To be able to anticipate and prevent collapses, or increase the abundance of a desired species, we need to understand what controls species abundance and distribution.

Species distribution and abundance depend largely on the habitat requirements of an animal. These requirements are the drivers of species abundance and distribution. For clarity, in this study "habitat requirements" is defined as: "(A)biotic features of the environment that are necessary for the persistence of individuals or populations." (2). The range of an abiotic or biotic factor in which an organism is able to survive. (ie. "Corals require salinities between 30 and 40 parts per thousand"). All habitat requirements combined determine the boundaries of an organism's habitat. And these requirements often change throughout the lifecycle of an animal.

Abiotic and biotic factors have always been dynamic in nature, across different timescales. Temperature being one of the most obvious examples of how dynamic these factors can be. It can vary over timescales of 100.000 s of years in the form of glacials and interglacials, to the smaller Milankovitch cycles of 1000 s of years, to the timescales of around 10 years between $\mathrm{EI}$ Niños and El Niñas, to monthly seasonal differences all the way down to differences in the day-night cycle (3). Although sometimes less obvious than temperature, many more (a)biotic factors have also shown great variation throughout history, including salinity, wind, $\mathrm{pH}$ and solar radiation $(4,5)$.

These changes and fluctuations in (a)biotic factors can have great consequences for an animal's abundance and distribution. In recent years and the years to come, many of these (a)biotic factors change faster than ever due to human impact. If burning of fossil fuels persists, global warming will exceed a $2 \mathrm{C}$ increase above pre-industrial average surface temperature (6) and $\mathrm{pH}$ of surface waters is predicted to reduce by $0.3-0.5$ units by the year 2100 through ocean acidification (7). Environmental pollution can lead to big changes in coastal nutrient concentrations through discharges from wastewater treatment plants, rivers and coastal run-off (8). Natural habitats are disturbed by human activities like bottom trawling, that change the structure and composition of the seabed (9). To be able to make predictions on how the abundance and distribution of a species will change and protect the people that dependent on them, it is important to identify which (a)biotic factors have an important role in controlling abundance and distribution.

Because habitat requirements are complex and time consuming to research, most researchers focus on only a small part of an organisms life cycle. Embryo and larvae are generally considered the most vulnerable life stages to altered environmental conditions (10). However, many organisms and especially marine invertebrates, undergo several ontogenetic and ecological transitions throughout their life cycle. Hence, each stage can differ in sensitivity to environmental stressors (11). Also, when experiments are focussed on a single life stage, processes like acclimation, selection and carryover between successive life stages are ignored. So to know the true impact of (a)biotic factors on a species distribution and abundance, the whole life cycle should be considered.

The main aim of this project is to illustrate a fast and relatively simple approach to gain knowledge on the importance of certain habitat requirements in controlling species abundance and distribution, by comparing habitat requirements of a species' life stages with the (a)biotic values found in nature. This is illustrated through a detailed case study of the sea urchin species, Psammechinus miliaris.

I then display the kind of conclusions and knowledge gaps that can be discovered, when this approach is used. Also, I aim to identify the strong-and weak points of this approach. 


\section{The case study}

Sea urchins are free spawning organisms that send their gametes freely into the water column. They have a free swimming planktonic larval stage and a benthic adult life stage. In this case study, 6 important life cycle stages are separated: gametes, embryo, larvae, metamorphosis, juveniles and adults.

The green sea urchin, Psammechinus miliaris is a common sea urchin in the coastal areas of the Netherlands. Removal experiments by Hughes et al. (2006) have shown that $P$. miliaris' grazing activity has a major impact on the structure and distribution of benthic marine organisms ((12) as cited by (13)). Therefore it is likely to be a keystone species in the coastal areas of the Netherlands. In the past years, due to overfishing and depletion of sea urchin stocks, interest in the aquaculture of $P$. miliaris has grown (14-16). P. miliaris is one of the more palatable sea urchins and its reproductive stages are relatively easy to acquire and keep in the laboratory $(13,17)$. P. miliaris has also been reported to clean undesirable fouling organisms on mussel rope cultures (18). Therefore, $P$. miliaris has great potential for aquaculture. And due to the well-established reproductive and larval rearing methodology it is a good model organism for experimental studies (19).

P. miliaris observations has varied greatly over the years $(20,21)$. This makes it an interesting organism for studying the (a)biotic factors and habitat requirements that are responsible for these fluctuations. To be able to make predictions for both (sea-based) aquaculture and the management and preservation of North Sea ecology, it is important to understand which habitat requirements are most likely to affect $P$. miliaris abundance and distribution. Therefore the following main research question was formulated: which $P$. miliaris habitat requirements are most likely to be limiting factors in the Eastern Scheldt, Grevelingen and the North sea? I hypothesise that temperature, substrate/bottom type, predation and food availability play the biggest roles in determining the distribution and abundance of $P$. miliaris in the Eastern Scheldt, Grevelingen and North Sea. To be able to answer the main research question, the following two subquestions first require to be answered: first, what are $P$. miliaris' habitat requirements for each of its life stages? And second, what are the relevant abiotic factors (or habitat characteristics) in the Eastern Scheldt, Grevelingen and North sea?

The aims of the case study are to identify $P$. miliaris' (a)biotic requirements for diet, food quantity, hydrodynamics, oxygen, $\mathrm{pH}$, hydrostatic pressure, salinity, substrate and temperature. These requirements will be related to the (a)biotic conditions reported for the Eastern Scheldt, Grevelingen and North Sea. This is done in order to evaluate which habitat requirements are most likely limiting factors for $P$. miliaris and thus influencing its abundance and distribution in the study area. These results may explain fluctuations in $P$. miliaris observations in the Grevelingen and Eastern Scheldt. Knowledge gaps in habitat requirements of the complete $P$. miliaris and other sea urchin life cycles will also become clear.

\section{Methods}

\section{Stepwise description of the approach}

Step 1: Problem definition, two options

a. Start with a natural system with an important ecology and then pick a specific species that is important to the ecological functioning of the system, or;

b. Start with an important species and then select a study area based on the distribution of the species and the societal and economic importance of the species in the area.

Step 2: Determine which (a)biotic factors should be studied based on the importance of these factors in conspecifics.

Step 3: Attain a profound understanding of the species' life cycle and determine all important life cycle stages.

Step 4: Determine the minimum, maximum and average values of the selected (a)biotic factors in the study area. This can be done through literature studies, if the information is available, and otherwise they can be determined through measurements.

Step 5: Determine the minimum, maximum and optimum habitat requirements of each of the 
species' life stages, for all selected (a)biotic factors. This can be done through literature studies, if the information is available, and otherwise they can be determined through laboratory experiments.

Step 6: Compare the minima and maxima of habitat requirements with minima and maxima of the (a)biotic factors in the study area to the determine the importance of (a)biotic factors in controlling abundance and distribution of the species:

a. If minimum habitat requirements are all much lower than minimum (a)biotic factors and if maximum habitat requirements are all much higher than maximum (a)biotic factors the conclusion is: The specific factor is likely not a limiting factor for species abundance and distribution

b. If minimum habitat requirements are all much higher than minimum (a)biotic factors or if maximum habitat requirements are all much lower than maximum (a)biotic factors the conclusion is: The specific factor is likely to be a limiting factor for species abundance and distribution

c. If the minima and maxima of habitat requirements are close to the minima and maxima values of the study area then the current importance of the factor is debateable, but may be vulnerable to change.

Step 7: Knowledge gap analysis is carried out to explore the available data on conspecifics and how that relates to the conclusions

\section{Methods of the case study}

Step 1: Firstly, Psammechinus miliaris was selected because a) it has well characterised habitat requirements, b) it has potential for aquaculture, c) it can have profound effects on ecosystem structure and d) $P$. miliaris abundances have been shown to fluctuate over the years. Then the study area of the Eastern Scheldt, Grevelingen and North Sea (Figure 1) was selected as they are a) protected Natura 2000 areas, b) important to fisheries, shellfish farming and recreation, c) important feeding grounds to many protected bird species, and d) $P$. miliaris is one of the most common sea urchin species in the area. Also, observational data

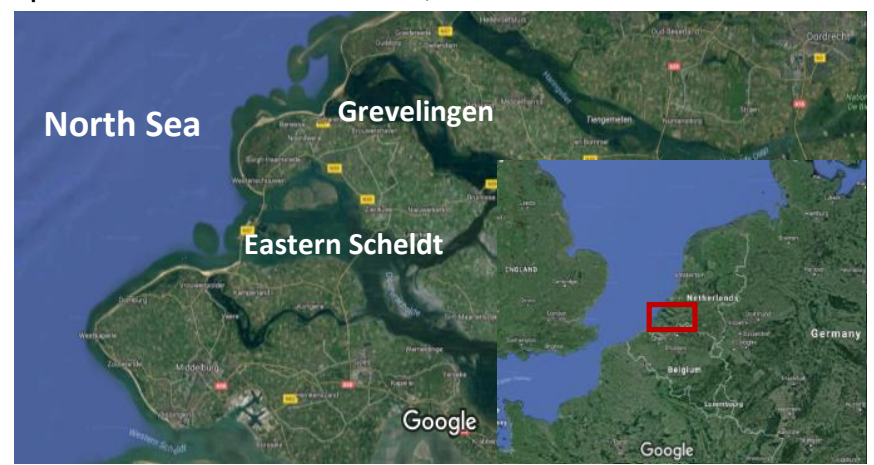

Figure 1; Study area (87).

from stichting ANEMOON and temperature data from Rijkswaterstaat were available to explore the relationship between the yearly differences in water temperature and $P$. miliaris abundance in the Eastern Scheldt and Grevelingen Lake.

Step 2: Nine biotic and abiotic factors were studied, namely diet, food quantity, hydrodynamics, oxygen, hydrostatic pressure, salinity, bottom type / substrate, $\mathrm{pH}$ and temperature. As these have all -at least to some extend- been considered important sea urchin habitat requirements $(18,22-27)$.

Step 3: After studying the $P$. miliaris life cycle in literature, six distinct life cycle stages: gametes, embryo, larvae, metamorphosis, juveniles and adults were determined.

Step 4: For each of the (a)biotic factors, the minimum, maximum and average values were determined in the Grevelingen, North Sea and Eastern Scheldt through a literature study, using the search engines Scopus and the Wageningen University Library Global search. Google Scholar was used for snowballing and to look up primary references. The search was done in the period December 2016 - March 2017. Only papers in English and Dutch were included. The search words used were the names of the study areas; "Grevelingen", "North Sea" and "Eastern Scheldt" in combination with keywords for all of the habitat requirements that can be found in table 1.

Step 5: To determine the habitat requirements of each of the life stages, the same search engines and criteria were used as in step 3 . Only now, the key word "Psammechinus miliaris" was used and gave about 200 search results. The articles that contained information on habitat requirements were selected for further reading. Snowballing was however the biggest 
Table 1. Key words used for search result analysis for the main habitat requirements and the main sea urchin life stages in combination with the search terms: (Sea urchin" OR "Sea urchins".) and "Psammechinus miliaris"

\begin{tabular}{|c|c|}
\hline Habitat requirements & Life stages \\
\hline "pH" & $\begin{array}{l}\text { ("Gamete" OR "Gametes" OR "Sperm" OR "Eggs OR } \\
\text { "Egg") }\end{array}$ \\
\hline "Temperature" & ("Embryo" OR "Embryos") \\
\hline "Hydrostatic pressure" & ("Larvae" OR "Larva" OR "Larval") \\
\hline "Salinity" & ("Metamorphosis" OR "Settlement" OR "Recruitment") \\
\hline ("Hydrodynamics" OR "hydrodynamic" OR "flow speed") & ("Juvenile" OR "Juveniles") \\
\hline ("Diet" OR "Diets") & ("Adult" OR "Adult") \\
\hline \multicolumn{2}{|l|}{$\begin{array}{l}\text { ("Bottom type" OR "Bottom material" OR "Hard substrates" OR "Soft } \\
\text { substrates" OR "hard substrate" OR "Soft substrate" OR "Bottom } \\
\text { habitat") }\end{array}$} \\
\hline \multicolumn{2}{|l|}{ ("Oxygen" OR "Hypoxic") } \\
\hline "Food quantity" & \\
\hline
\end{tabular}

source of valuable articles on habitat requirements. Mendeley was used to manage references. The habitat requirement found in experimental studies were given priority, where minima and maxima are the first values at which $100 \%$ mortality occurs. The optimum values are the values at which growth and survival conditions are the highest. If no experimental data was found, the most extreme values at which $P$. miliaris had been observed in nature, were considered as the minimum and maximum habitat requirements. Observational data was mostly on adults.

Furthermore, I extended the literature search by comparing data of $P$. miliaris observations and water temperatures in the Eastern Scheldt and Grevelingen Lake to explore the relationship between the yearly differences in water temperature and $P$. miliaris abundance over a 22 year period.

Data on $P$. miliaris observations in the Eastern Scheldt and Grevelingen since 1994 wasobtained from Stichting ANEMOON, a nonprofit organisation that collects observations from Dutch recreational divers (28). To correct for the amount of observations and the differences in periodical observation intensity, the average encounter rate was calculated per year. Encounter rate is the percentage of all observations from one year that encountered at least one individual of $P$. miliaris during a dive. Water temperature data was collected by Rijkswaterstaat (Dutch government) from two measuring buoys in the Eastern Scheldt and one measuring buoy in the Grevelingen. These buoys measure water temperature every 10 minutes, and all data from 1994 up to 2016 was used (29). The average water temperature was then calculated per day. Organisms can generally survive short periods of extreme temperatures, but survival decreases when the occurrence of extreme temperatures increases. Therefore, the amount of days per winter that had an average temperature below a certain threshold, was determined, referred to as "cold days per winter". For instance the amount of days in the months November 2001 - February 2002 with an average water temperature below $1{ }^{\circ} \mathrm{C}$. When data point were missing, values were corrected for the amount of days for which data was available, by calculation the percentage of cold days per winter (amount of days below $1{ }^{\circ} \mathrm{C}$ was divided by the amount of days that were available for that specific winter). Then, a Pearson correlation test was carried out between the percentage cold days per winter and the $P$. miliaris encounter rate.

Step 6: The minimum and maximum value of a reported habitat requirement were compared to minima and maxima of the (a)biotic factors in the study area to the determine the importance of (a)biotic factors in controlling abundance and distribution of $P$. miliaris.

Step 7: Research focus comparison was carried out to explore the available data on conspecifics and how that relates to my conclusions. The Scopus search engine was used, on 21-01-2017. Selection criteria were: Published: 1970 Present, Document type: Article or review, Searched in: Title, abstract and keywords. Table 1 shows all the key words that were used in the search. 


\section{Results}

\section{The Psammechinus miliaris life cycle}

Sea urchins are free-spawning organisms that send their gametes freely into the water column. They have a free swimming planktonic larval stage and a benthic adult life stage. Six important life cycle stages are separated: Gametes, embryo, larvae, metamorphosis, juveniles and adults (Figure 3 ).

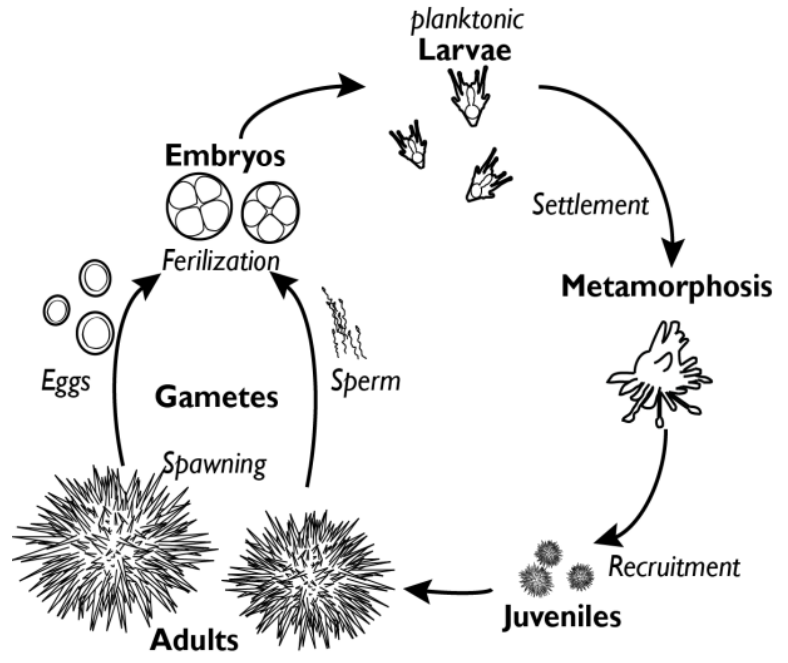

Figure 3; The Psammechinus miliaris life cycle

Spawning is likely to be stimulated by photoperiod and not temperature (30). As the days lengthen, $P$. miliaris starts spawning. Spawning period differs between locations but is generally somewhere between May and October (18). A female $P$. miliaris produces between 80.000 and 2.500 .000 eggs in a single spawning event (31). P. miliaris only spawns during a single spawning period, there is no evidence of any secondary spawning events (17). The Embryo stage starts when the $P$. miliaris egg is fertilized, after about $48 \mathrm{~h}$ when the stomach forms and the planktonic larval stage is initiated (26). Larvae are competent for settlement as soon as 20-21 days (26). When a suitable surface is found to settle on, the larvae starts its metamorphosis. In the laboratory, a surface covered with a mixture of algae and bacteria can induce settlement (32). When settled, the metamorphosis stage is initiated. After 5-7 days, the digestive tract is formed and the juvenile stage has begun (33). Figure 2 shows the complete metamorphosis of a
Lytechinus pictus sea urchin, from larvae to juvenile (32). Development is very similar in all echoinoids. Individuals are considered adult as soon as they are sexually reproductive. $P$. miliaris individuals have been found to be sexually mature in its first year, $((34,35)$ as cited by (18)). Growth of adults and juveniles is maximal in early spring/summer months and growth rates slow over winter (36)(37). Most of

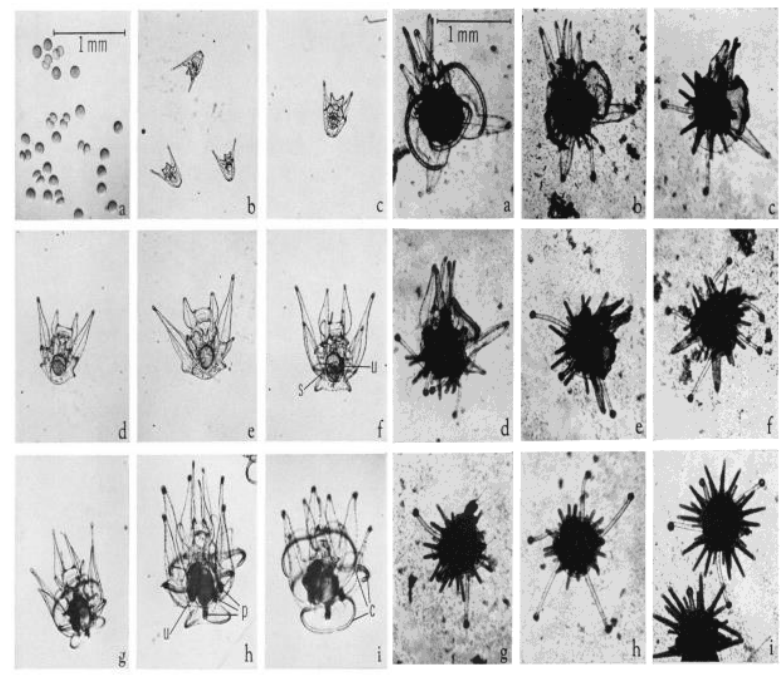

Figure 2; Development from fertilized egg to juvenile at different time intervals of the echinoid Lytechinus pictus. Adapted from Hinegardner (1969) (12).

the adult growth is completed at 3 years (38) and individuals may reach an age of more than 10 years (39).

\section{Habitat and distribution}

$P$. miliaris occurs in a diverse range of habitats (18) and is common throughout the North Sea (40), Grevelingen and Eastern Scheldt (21). It is also found around the British Isles, as far north as Scandinavia and as far south as Morocco but not in the Mediterranean ((41) as cited by (13)). In these areas, densities vary greatly with habitat type (13), with high densities mostly found in shallow or littoral locations (18). Even so, some $P$. miliaris populations can be found up to depths of 100 meters (41), while others are exposed to air at low spring tides (42)

\section{Search result comparison:}

The least researched habitat requirements for both sea urchins (Figure $4 A$ ) and $P$. miliaris (Figure 4B) are hydrostatic pressure, salinity, 
hydrodynamics, bottom type and food quantity. For sea urchins the most researched are $\mathrm{pH}$ and temperature. This can be explained by the widely held assumption that calcifying organisms like echinoids are more vulnerable to ocean acidification than non-calcifying organisms (43). For $P$. miliaris diet is the most researched habitat requirement, mostly for aquaculture purposes. For both sea urchins and $P$. miliaris, the least researched life stages are the juvenile, metamorphosis and adult stage (Figure $4 C, D$ ). The early life stages probably gain much attention since sea urchins have been widely used as model organisms for embryo development (42).

Almost none of the researched habitat requirements had research conducted towards all $P$. miliaris life stages (Figure 5B). Only $\mathrm{pH}$ was mentioned at least once in combination with
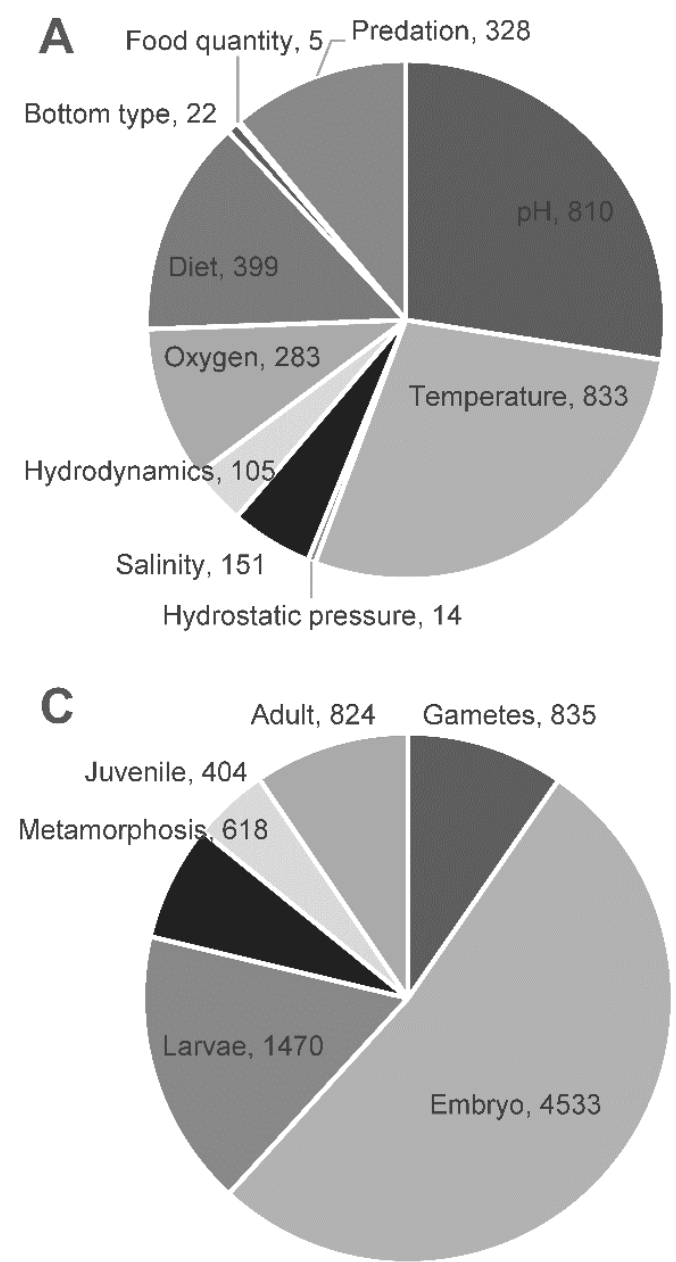

each of $P$. miliaris' life stages. Hydrostatic pressure was only researched for the gamete and embryo stages and not for later sea urchin life stages (Figure 5A).

Although Figure 5 gives an idea of the available information, in practice some of the articles were not usable and some additional articles that contained valuable information were found through snowballing.

\section{Habitat requirements and natural values}

I will relate information that was found on each of the habitat requirements and life stages that were considered. As well as the information on the relevant natural (a)biotic factors in the study area.

\section{Diet}

In the laboratory, various microalgae are
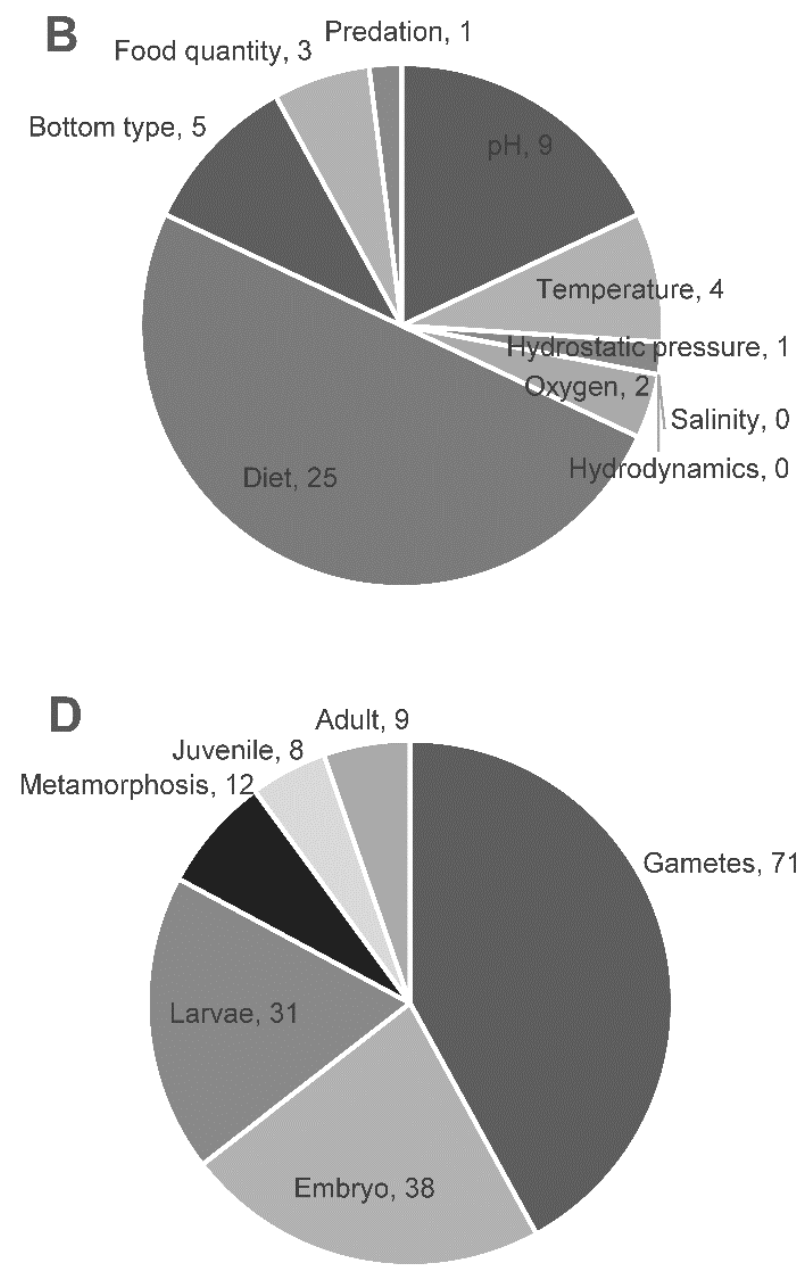

Figure 4; Amount of search results for (A) Sea urchin habitat requirements, (B) Psammechinus miliaris habitat requirements, (C) Sea urchin life stages and (D) Psammechinus miliaris life stages 

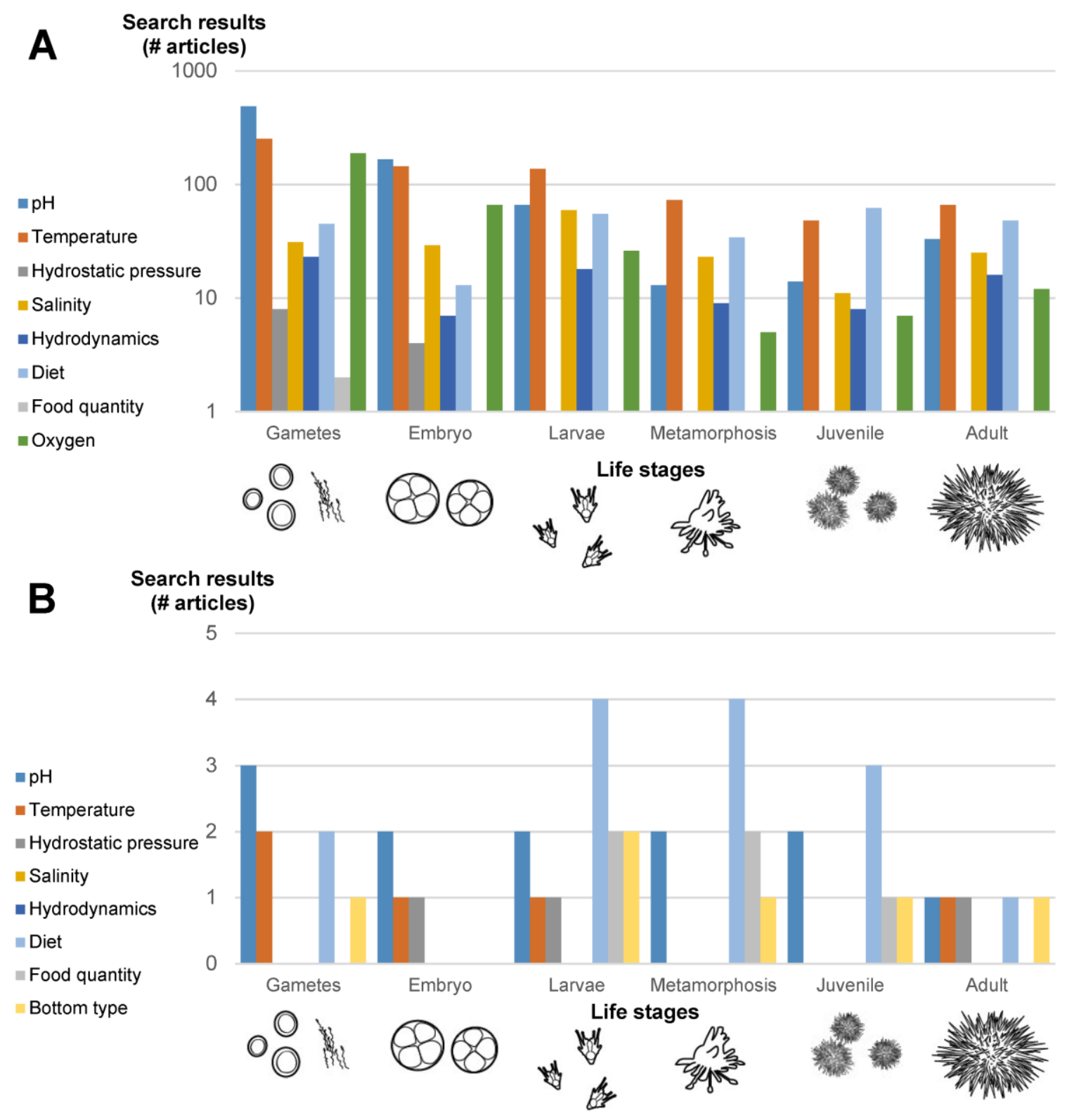

Figure 5; Habitat requirements search results per life stage for (A) Sea urchins and (B) Psammechinus miliaris

adequate food sources for $P$. miliaris larvae but the species Dunaliella tertiolecta is preferred for larger percentage of juveniles reach metamorphosis and larger juveniles are produced (26). Adults and juveniles are generalist, they graze on a huge variety of organisms. Analysis of gut content showed that $P$. miliaris feeds on hydroids, worms, echinoderms, crustaceans, diatoms, molluscs, bottom material, fresh plants, dead fragments of algae and animals on plants (13). P. miliaris individuals in aquaria were found to graze on a great variety of food, including barnacles, molluscs, bryozoans, ascidians, worms, aquaculture and experimental studies as a

hydroids, small sponges, any kind of seaweed, dead crab and fish and feaces of crab and fish (44). Jensen (1969) reported better growth rates in $P$. miliaris feeding on Laminaria saccharina with epizoic animals than on clean $L$. saccharina (38).

High protein diets increase growth rates of adult and juvenile sea urchins significantly (16) (45). Additionally, when given the choice between the two macroalgae: Palmaria palmata and Laminaria digitate, $P$. miliaris adults showed a stronger preference for $P$. palmata. Which has 
been credited to the high protein levels in $P$. palmata (45).

The Eastern Scheldt, Grevelingen and North Sea have a large variety of microalgae species available to $P$. miliaris larvae. The large range of organisms consumed by adults and juveniles are available throughout the North Sea, Eastern Scheldt and Grevelingen.

\section{Food quantity}

P. miliaris larvae fed a low amount of

A

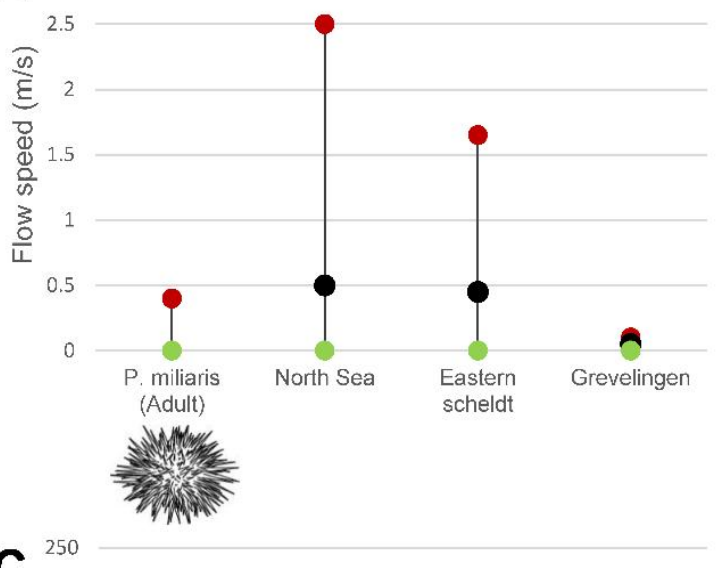

C
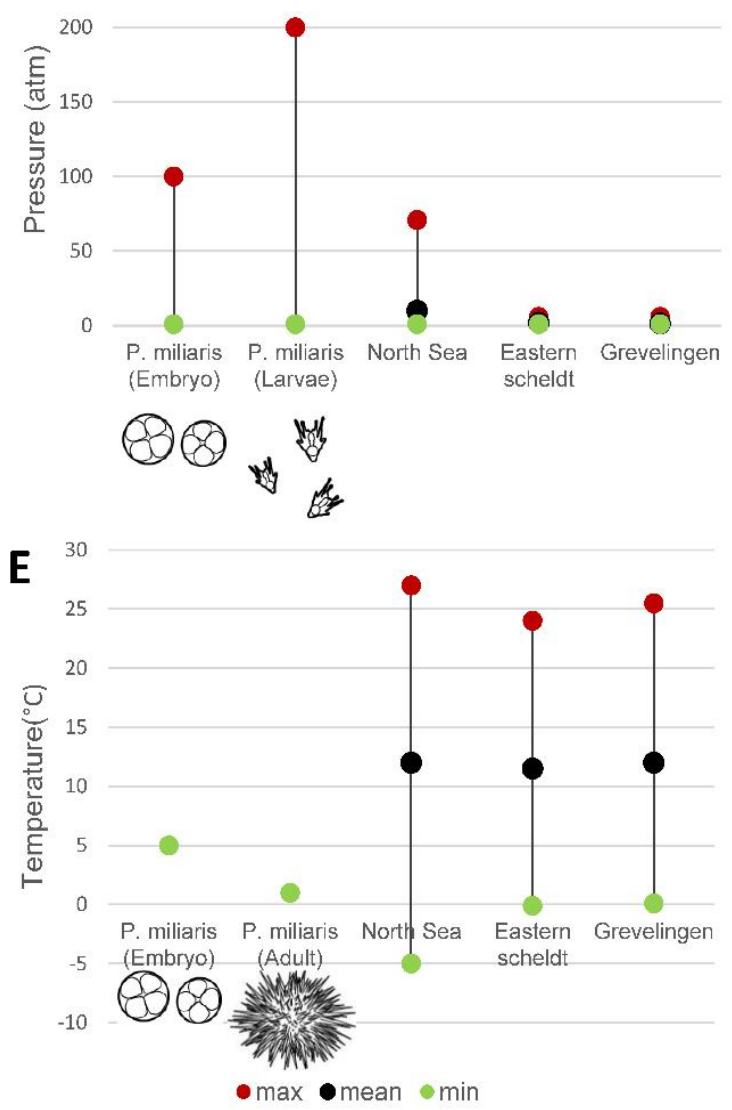

microalgae $D$. tertiolecta (500 cells $/ \mathrm{ml}$ ) did not develop to metamorphosis. Larvae fed a high amount of microalgae (4000 cells $/ \mathrm{ml}$ ) could not maintain their position in the water column and fell to the bottom (26). The optimal diet depends on larval developmental stage $(26,32,46)$. For the two, three and four armed larval stages, feeding rate was 1500,4500 and 7500 cells/ml per day respectively (46). Larvae have been shown to survive periods of up to 11 days without food (46).
B
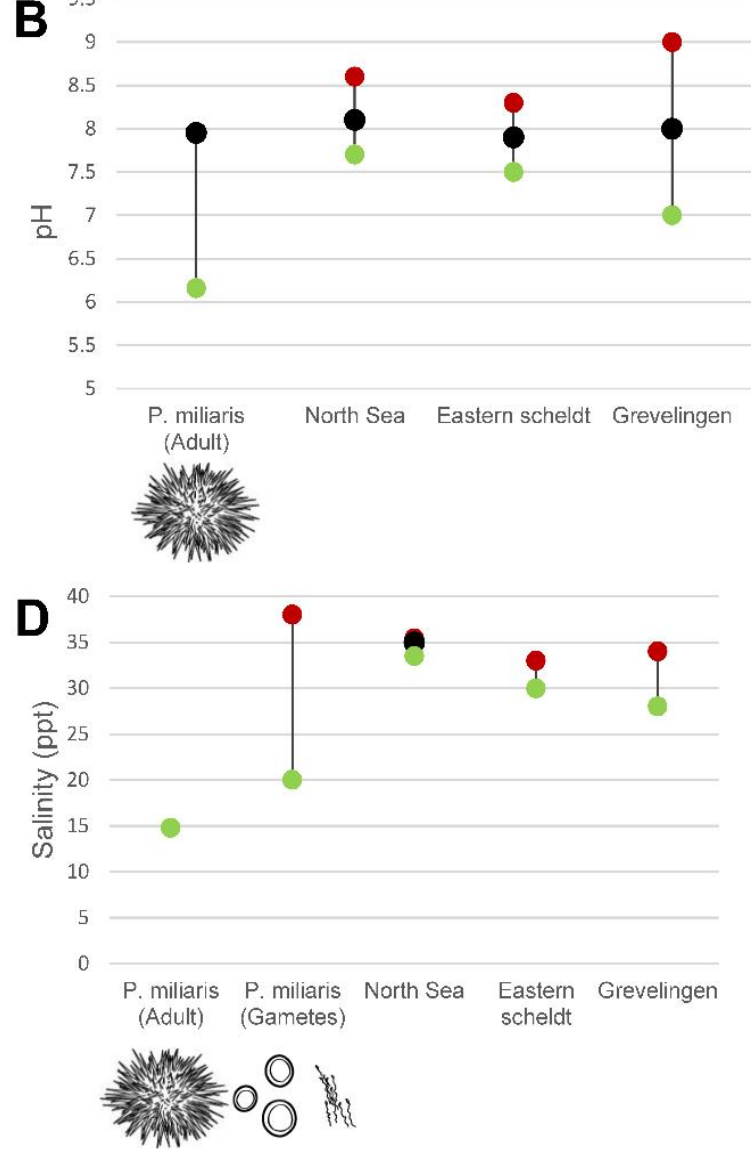

Figure 6; Minimum and maximum values of the Psammechinus miliaris habitat requirements for different life stages and the minimum and maximum values that occur in the North Sea, Eastern Scheldt and Grevelingen. For the abiotic factors:

Hydrodynamics $(A), \mathrm{pH}(\mathrm{B})$, hydrostatic pressure $(\mathrm{C})$, salinity (D) and temperature (E). 
Unfortunately no studies were found to be concentrations or adult and juvenile food biomass in the Grevelingen, North Sea and Eastern Scheldt.

\section{Hydrodynamics}

In Scotland, P. miliaris typically occurs in dense populations in sheltered areas of sea lochs (18). This suggests it prefers sheltered, low flow speed areas. Still, in the English channel $P$. miliaris was found to be characterized by a relatively high near bed velocity of $>0.4 \mathrm{~m} / \mathrm{s}$ (23).

Figure 6A shows that North Sea and Eastern Scheldt the water currents can reach speeds that are much higher than the speed at which $P$. miliaris is generally observed. While water currents in the Grevelingen never exceed the maximum speed at which $P$. miliaris was observed.

\section{Oxygen}

Experiments by Spicer has shown that $P$. miliaris adults are unable to regulate oxygen uptake during progressive hypoxia (low oxygen concentrations). However, they do occupy environments exposed to strong hypoxic events, such as intertidal shores (24). As long as the hypoxic event is brief, it does not have severe negative effects on the sea urchins organs (24). Spicer does however not discuss the effect of longer exposure times to hypoxia. Large scale stratification has led to deoxygenation of the Grevelingen lake (47). During summer months, the water column is completely anoxic $\left(<2 \mathrm{mg} / \mathrm{I}_{2}\right)$ below depths of 15 meters (48). So in the Grevelingen, $P$. miliaris can very well be exposed to anoxic water during long periods of time.

\section{$\mathrm{pH}$}

P. miliaris sperm has been observed to have an improved swimming speed at reduced seawater $\mathrm{pH}$ (from 8.06 to 7.67) (49). Caldwell suggests that current seawater $\mathrm{pH}$ levels may be suboptimal for maximal sperm swimming speeds and may therefore even benefit certain aspects of the $P$. miliaris reproductive cycle. conducted towards phytoplankton

Increased swimming speeds may however have negative effects on longevity.

In an experimental study by Miles et al. (2007), mortality occurred in adults of $P$. miliaris exposed to a pH of 6.63 , but not until day 8 of exposure, while exposure to a $\mathrm{pH}$ of 6.16 resulted in changes to mobility and morphology prior to death. Most spines were lost and calcareous test was visible (50). Miles suggests that longer term exposure at a pH of 7.44, may have negative effects on adult survival. To avoid reduction in sea urchin adult survival, surface ocean $\mathrm{pH}$ lower than 7.5 should be avoided (50). An experimental study by Coleen et al. (2013) exposed $P$. miliaris adults and their offspring to a reduction in $\mathrm{pH}$ (from 7.98 to 7.7), from 42 days before spawning up to juvenile recruitment. The lower $\mathrm{pH}$ values negatively affected larval survival, but juvenile recruitment was the same across treatments (27).

The minimum $\mathrm{pH}$ in the Grevelingen, Eastern Scheldt and North Sea are between 7 and 7.7 while the minimum values adult $P$. miliaris individuals can survive are much lower than that (Figure 6; B).

\section{Hydrostatic pressure}

Both $P$. miliaris embryos and larvae can survive at greater pressures than the known adult depth limits. With larvae surviving up to 200 atm and embryos up to $100 \mathrm{~atm}$, larvae showed a much greater potential for surviving at greater depths compared to embryos (22). Thus, both embryo and larvae can survive pressure conditions way beyond those encountered in the studied areas (Figure 6C).

\section{Salinity}

P. miliaris from deeper water show different salinity optima from those found in littoral locations ((25) as cited by (13)). Gezelius (1962) showed that eggs of the these two forms differed in the salinities over which fertilization was successful (for the deep-water forms 20-32, the littoral forms $26-38 \mathrm{ppt}$ at $\left.17-19^{\circ} \mathrm{C}\right)((51)$ as cited by (13)). In 1932, P. miliaris was observed to the north of Wieringen in the former 
Zuiderzee at a salinity of $15 \mathrm{ppt}$ (40). While in the Grevelingen, Eastern Scheldt and North Sea, the salinity values are all within the range of 28 ppt to 35.5 ppt. Both P. miliaris adults and gametes can survive values much lower than 28 ppt. Gametes can tolerate salinities of $38 \mathrm{ppt}$ which is higher but close to the maximum salinities found in the study area. And the maximum salinity tolerance of $32 \mathrm{ppt}$ for the deeper water form is within the range observed in nature (Figure 6D).

\section{Temperature}

A temperature of $5{ }^{\circ} \mathrm{C}$ does not allow embryo development (22). In Denmark, $P$. miliaris is found at locations where winter temperatures are just above zero and it was found to reproduce in waters where the summer temperatures rarely exceed $11 \circ \mathrm{C}(52)$. Littoral populations are more tolerant to increased temperature and decreased humidity during aerial exposure (53). Also, an article from 1968 claimed that the severely cold winter of 1963 likely eradicated most of the $P$. miliaris population in the Netherlands (20).

In the Eastern Scheldt, Grevelingen and North Sea temperature varies from temperatures just below zero up to temperatures of around $25^{\circ} \mathrm{C}$, while the minimum habitat requirement for $P$. miliaris embryos is at about $5{ }^{\circ} \mathrm{C}$ (Figure 6E).

After examining the relationship between $P$. miliaris encounter rate and temperature, the amount of cold days per winter below $1{ }^{\circ} \mathrm{C}$ (figure 7E) was found to be correlated with the $P$. miliaris encounter rate in the Eastern Scheldt (figure 7C) $[r=-0.578, n=18, p=0.009]$. This was not apparent between these two variables in the Grevelingen (figure 7AB) $[r=-0.434, n=$

\section{Grevelingen}
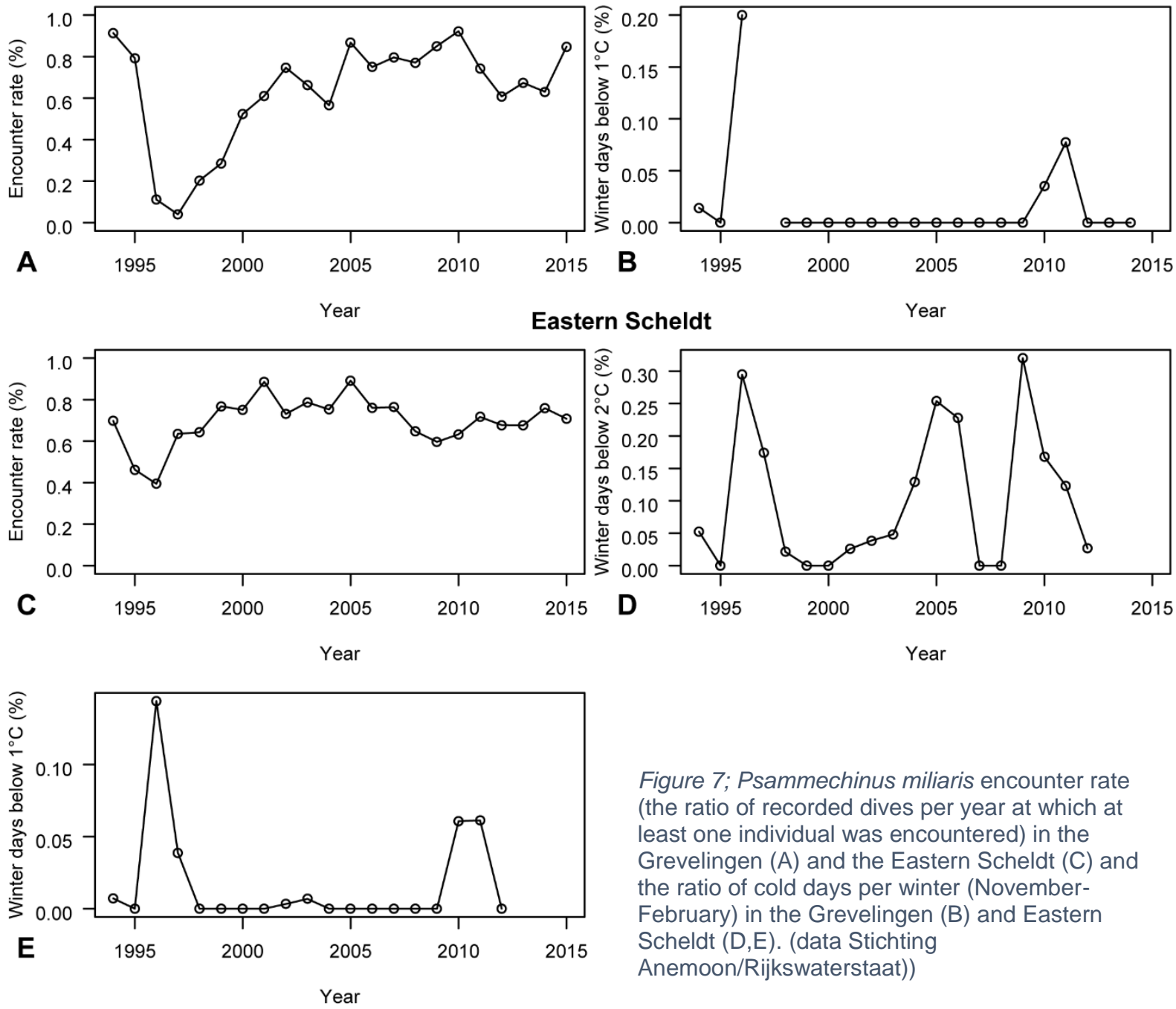

Figure 7; Psammechinus miliaris encounter rate (the ratio of recorded dives per year at which at least one individual was encountered) in the Grevelingen (A) and the Eastern Scheldt $(C)$ and the ratio of cold days per winter (NovemberFebruary) in the Grevelingen (B) and Eastern Scheldt $(D, E)$. (data Stichting

Anemoon/Rijkswaterstaat)) 
$19, p=0.056]$. Also, no relationship was found between cold days below $2 \circ \mathrm{C}$ (Figure 7D) and $P$. miliaris encounter rate in the Eastern Scheldt (figure $7 C$ ) $[r=-0.231, n=18, p=0.341]$.

\section{Bottom type}

P. miliaris adults generally prefer hard substrates: As they are mostly found attached to the undersides of rocks and buried under gravel on the foreshore(18), they are abundant on oyster banks in the German and Danish Waddensea (18), in the English channel $P$. miliaris was found to be characterized by relatively high amounts of rock and shell components (23) and in Ireland, P.miliaris has been reported to be abundant on suspended rope cultures of mussels ((33) as cited by (18)). $P$. miliaris distribution has been found to coincide with Laminaria saccharina, on fronds and the rocky surfaces below them (18). Although $P$. miliaris has also been reported to prefers sandy grounds (40). The bottom type in the Grevelingen, North Sea and Eastern Scheldt mostly consists of soft, sandy substrates (5457). The relatively small areas consisting of hard substrates include rocky reefs, oyster banks, shipwrecks and rocky shores from coastal protective dikes $(58,59)$

\section{Predators}

Many different planktonic invertebrate- and vertebrate predators, and benthic suspension feeders predate on echinoid larvae (42). Predation is likely to be one of the most important sources of mortality (60) and has even been suggested to be the main source of planktonic larval mortality (61). Mortality rates have been estimated from field studies to be in the range of $6-27 \%$ per day $(60,62)$. Not much is known about predation on adult and juvenile $P$. miliaris in the North Sea. P. miliaris was however reported as an important food source for the velvet swimming crab Necora puber in Galicia, NW Spain (63). Additionally, in the Irish sea, it was also reported as one of the most important food sources for the seven armed sea star Luidia ciliaris (64). Necora puber is a common crab species in the Eastern Scheldt,
Grevelingen and North Sea (21,65). Luidia ciliaris does not occur in the Grevelingen, North Sea and Eastern Scheldt (66).

\section{Discussion}

\section{Main conclusions}

We found Psammechinus miliaris' habitat requirements for each of its life stages?" and Most of the measurable (a)biotic factors (or natural values) in the North Sea, Grevelingen and Eastern Scheldt were found (figure 6 and appendix, table 4-6). Only food quantity values are missing for all study areas. Unfortunately none of the researched (a)biotic factors had information available on the habitat requirements of all six life stages. And of all the measurable (a)biotic factors, only oxygen concentration had no information available on $P$. miliaris habitat requirements (appendix, table 7).

\section{Larval diet and food quantity}

As many microalgae species are adequate food sources for $P$. miliaris larvae, the availability of specific algal species is probably not extremely important to $P$. miliaris. Although larval habitat requirements for food quantity are well researched, it is hard to draw conclusions on the importance of food quantity, as no information was found on food quantity in the study area. Although conclusions cannot be drawn for $P$. miliaris specifically, larval growth of several species of sea urchin and other invertebrates have been shown to be food limited in coastal waters, significantly extending the time for larvae to reach metamorphosis $(67,68)$. Longer development times can have huge consequences for species abundance and distribution, because echinoid larval stages are generally associated with large mortality rates (in the range of $6-27 \%$ per day) $(42,60,62)$. And one might argue that when larval development time is extended, this leaves them exposed to ocean currents for longer periods of time, allowing them to be carried over larger distances until they reach metamorphosis. However, to the authors knowledge, no information is available on the distribution $P$. 
miliaris larvae but this might be an interesting area of research.

\section{Adult and juvenile diet and food quantity}

Food is probably unlikely to be limiting to adult and juvenile $P$. miliaris distribution due to the huge variety of organisms it is able to feed on. This is supported by Faller-Fritsch and Emson (1972) (from (69)), who concluded that $P$. miliaris distribution is more likely to be limited by physical factors than food availability.

It would however require some estimates of available food biomass in the study area, biomass requirements per $P$. miliaris individual and the amount of individuals present in the study area to be able to draw reliable conclusions on whether food availability is a limiting factor to $P$. miliaris abundance and distribution.

\section{Hydrodynamics}

Water currents are important to dispersal of echinoid larvae (42), and thus, high flow speeds may be advantageous to $P$. miliaris distribution. Too high flow speeds can however be unfavourable, when larvae are dispersed beyond the geographical region of their suitable habitats. Additionally, rapid currents can severely limit fertilization success due to dilution of gametes (42). Also, adults and juveniles may be exposed to much stress when currents are too strong for them to remain attached to the substratum.

As currents in the Eastern Scheldt and North Sea can reach much higher flow speeds than the speed at which $P$. miliaris is generally observed, I conclude that hydrodynamics is a very important factor in determining $P$. miliaris distribution in the Eastern Scheldt and North Sea. It would be interesting to conduct experiments to test for the effects of water currents on all life stages of $P$. miliaris, also it would be interesting to look for a relationship between $P$. miliaris observations and flow speeds.

\section{Oxygen}

Due to stratification in the Grevelingen lake, $P$. miliaris individuals are likely to be exposed to anoxic conditions. $P$. miliaris adults are not affected by brief events of low oxygen concentrations, but the effect of longer exposure times is unknown. The effect of oxygen concentrations on other $P$. miliaris life stages is yet to be determined.

\section{$p H$}

This suggests that, although low $\mathrm{pH}$ values caused reduced survival in larvae, in the end it does not affect $P$. miliaris abundance.

Short term adult mortality due to low $\mathrm{pH}$ values occurs at a pH of 6.16, but negative effects do already occur at longer term exposure to a $\mathrm{pH}$ of 7.44. These values are mostly outside the $\mathrm{pH}$ ranges observed in the Grevelingen, Eastern Scheldt and North sea.

However, pH of worldwide ocean surface waters have been predicted to decrease with 0.4 units before 2100 and 0.7 units by 2250 due to ocean acidification (7). This reduction would decrease the mean $\mathrm{pH}$ in the study area from 8 now to 7.6 in 2100 and 7.3 in 2250 and from the minimum pH of about 7.6 now to 7.2 in 2100 and 6.9 in 2250. They would come close, but not exceed the $P$. miliaris minimum adult habitat requirements. However, it does exceed the $\mathrm{pH}$ value of 7.44 at which negative effects have already been observed. Thus, it could have negative effects on $P$. miliaris abundance and distribution.

So as of now, $\mathrm{pH}$ is unlikely to affect $P$. miliaris abundance and distribution. But that may change in years to come due to ocean acidification.

\section{Hydrostatic pressure}

Both embryo and larvae can survive pressure conditions way beyond those encountered in the Grevelingen, Eastern Scheldt and North Sea. Based on those results, it would be safe to conclude that hydrostatic pressure is not a limiting factor to $P$. miliaris. It does however raise the question why $P$. miliaris is not encountered below depths of $100 \mathrm{~m}$, if this is not explained by pressure conditions. To be able to say for certain that pressure is not a limiting 
factor to $P$. miliaris in the study area, the hydrostatic pressure tolerance for the gamete, juvenile, metamorphosis and adult life stages should also be determined.

\section{Salinity}

The minimum salinity tolerance limits for both gametes and adults are way below the salinity values generally found in the study area. The maxima are only known for gametes, the deeper water ( $\mathrm{S}$ ) forms can fertilize over higher salinities than the maxima found in the study area. Although most results suggest that salinity is not a limiting factor, the eggs of littoral forms of $P$. miliaris do not fertilize at salinities above $32 \mathrm{ppt}$. While in the natural areas, $32 \mathrm{ppt}$ is quite commonly exceeded.

Based on the results, it would be safe to say that relatively low salinities in the Grevelingen, North Sea and Eastern Scheldt do not affect $P$. miliaris. However, more information on the maximum salinity tolerance is needed to safely say whether salinity can at times be a limiting factor for $P$. miliaris distribution and abundance in the natural areas.

\section{Temperature}

There was no significant correlation between $P$. miliaris encounter rate and the percentage of days below $2 \mathrm{C}$ in the Eastern Scheldt, but there was a strong negative correlation with the percentage days below $1 \mathrm{C}$. Although this might not necessarily be a causal relationship, this finding supports that cold winters negatively affect $P$. miliaris abundance as previously suggested by Wolff (20). This negative correlation may exist because the $P$. miliaris temperature tolerance lies somewhere around 1C. It would however require laboratory experiments to be certain what the $P$. miliaris minimum temperature tolerance is.

There was no significant correlation between encounter rate and cold days below $1 \mathrm{C}$ in the Grevelingen lake which suggests that the $P$. miliaris population in the Grevelingen is more resistant to low temperatures. However, we did observe a trend and missing data points may partly explain the lack of power. Thus, these findings indicate that more data on temperature is required and warrants further study.

These results also agree with the findings by Ursin (1960), that $P$. miliaris is found at locations where winter temperatures are just above zero (52).

P. miliaris embryos have been shown not to develop at temperatures of $5 \mathrm{C}$ and lower (22). Although the winter temperatures in the study area are often much lower than $5 \mathrm{C}$, the spawning period is not in winter and thus embryo are generally not exposed to temperatures lower than 5C. You could therefore conclude that low temperatures do not greatly affect embryos in the study area. But it does limit the period in which spawning is possible.

So in general, depending on the severity of the winter, temperature can be quite an important limiting factor to $P$. miliaris abundance and distribution in the Eastern Scheldt, Grevelingen and North Sea. The effect of high summer temperatures on abundance and distribution is still unknown.

\section{Substrate / Bottom type}

Several sources report that $P$. miliaris prefers hard substrates $(18,23,33)$, only a dated report by Engel (1932) states that $P$. miliaris prefers sandy grounds (40). As the bottom type of the Eastern Scheldt Grevelingen and North Sea mostly consists of soft, sandy substrates and relatively small areas consist of hard substrates, it is likely that bottom type is a very important limiting factor to $P$. miliaris abundance and distribution.

\section{Predation}

To the authors knowledge, no research was conducted towards predation on $P$. miliaris larvae specifically, but as most plankton feeders are generalists, predation on other (echinoid) larvae is likely to be very similar. Predation has been suggested to be the main source of planktonic larval mortality (61) or at least one of the most important sources of mortality (60). And thus, it may very well be a limiting factor in 
determining $P$. miliaris abundance and distribution.

There is very limited knowledge on the effect of predation on adult $P$. miliaris. Only two known predators where found, Necora puber and Luidia ciliaris, of which only $N$. puber occurs in the study area. But the mortality caused by $N$. puber is unknown.

Predation is certain to affect abundance and distribution, as it causes mortality. How severe these effects are, relative to all other factors that affect abundance and distribution, is unknown and requires further research.

\section{Debatable points of research}

To the authors knowledge, the most important (a)biotic factors have been taken into account in this study. Nevertheless, there are many more (a)biotic factors that can limit a species distribution and abundance. For instance; light intensity and length of day may be important, since photoperiod is the primary stimulus for $P$. miliaris spawning (30). Also, tidal differences may affect the distribution of $P$. miliaris in the littoral zone. And the availability of nutrients both in the food and in the water around the organism may also greatly limit distribution and abundance. These factors were however hard to relate to the study area and where thus not included in the study.

The exposure times to extreme values are not reflected in minimum and maximum values. Although an organism may survive extreme values for short periods of time, when it is exposed for longer periods of time it can negatively affect survival $(27,50)$. Also, the rate of change towards extreme values may also greatly affect an organisms response, as slower rates may allow an organism to acclimatize. When an organism is directly introduced to an experimentally altered (a)biotic factors, this may induce a stress response that may impact survival $(19,27)$. When the organism is introduced to an altered (a)biotic factor at a slower rate, this may have a less severe effect (19). Most of the experimental studies used to determine $P$. miliaris habitat requirements, that were used for this study have not taken this into account $(22,26,49-51)$. It would be wise to redo these experiments with the rate of change and exposure time taken into consideration. To investigate whether the same conclusions can be drawn.

Habitat requirements can differ within the defined life stages. For instance, within the larval life stage, multiple larval stages have been defined (2-, 3-, 4-, 6- and 8-armed pluteus), and these have been shown to have different feeding rates $(46,70)$. Hence, younger larvae require less available food. Also a juvenile of 1 week old may have relatively low survival chances when exposed to extreme (a)biotic values compared to an 8 month old juvenile.

The habitat requirements and natural values used in this study have come from many different sources using different methods, which can influence the comparability of studies. For example, differences in measuring devices, methods for determining habitat requirements and geographical areas where $P$. miliaris individuals were collected from. Hence, the values found do not fully represent reality. Therefore small trends may be hard to discover, but large differences between habitat requirements and natural values can lead to some reliable conclusions. It is also a great way of discovering knowledge gaps and can supply background for future research.

Lastly, the minimum and maximum habitat requirements may vary depending on the values of other (a)biotic factors. Such interaction effects have been reported for several (a)biotic

factors including temperature and $\mathrm{pH}$ (71), temperature and hydrostatic pressure (22) and $\mathrm{pH}$ and food availability (72). This is something this study did not take into account, as interaction effects are hard to study and would require a more mechanistic approach. To later construct models that are able to make powerful predictions of abundance and distribution of marine species, one must first understand how these interaction effects work. 


\section{Knowledge gaps}

Hydrodynamics and bottom type are two of the least researched habitat requirements in sea urchins (Figure 4A) and a large part of the life cycle has not been investigated (Table 2). Still, they are both very likely to be limiting factors in determining the distribution and abundance of P. miliaris and probably for sea urchins in general. Temperature is one of the most researched habitat requirements in sea urchins and with good reason, it is very probable to be an important limiting factor. Knowledge on temperature requirements of gametes, larvae, metamorphosis and juvenile stages is however still lacking for $P$. miliaris (Table 2). As well as the maximum temperature requirements of adults and embryos.

Table 2; Life stages per habitat requirement for which literature was available.

\begin{tabular}{|c|c|c|c|c|c|c|}
\hline Habitat requirement & Gamete & Embryo & Larva & Metamorphosis & Juvenile & Adult \\
\hline Diet & & & $\mathrm{X}$ & & $\mathrm{X}$ & $\mathrm{X}$ \\
\hline Food quantity & & & $\mathrm{X}$ & & & \\
\hline Hydrodynamics & & & & & & $\mathrm{X}$ \\
\hline Oxygen & & & & & & $\mathrm{X}$ \\
\hline $\mathrm{PH}$ & $\mathrm{x}$ & & & & & $\mathrm{x}$ \\
\hline Hydrostatic pressure & & $\mathrm{X}$ & $\mathrm{X}$ & & & \\
\hline Salinity & $x$ & & & & & $\mathrm{X}$ \\
\hline Temperature & & $\mathrm{X}$ & & & & $\mathrm{X}$ \\
\hline Bottom type & & & & $x$ & $\mathrm{x}$ & $\mathrm{X}$ \\
\hline Predation & & & $\mathrm{X}$ & & & $\mathrm{X}$ \\
\hline
\end{tabular}

Diet was well described for juvenile and adult $P$. miliaris, although the natural diet of larvae deserves some more attention. Information on food quantity requirements was missing for juveniles and adults (Table 2). Also, an estimation of food availability in the study area was missing for both larvae, juveniles and adults. Oxygen was also only researched for the adult life stage and the effect of longer exposure times to hypoxic conditions is unknown. Even though $\mathrm{pH}$ is fairly well researched for both sea urchins and $P$. miliaris (Figure $4 \mathrm{~A}, \mathrm{~B}$ ), habitat requirements were only found for the gamete and adult stages. For now, $\mathrm{pH}$ is unlikely to be a limiting factor to $P$. miliaris in the study area, but this may change in the future due to ocean acidification. Also, research on $\mathrm{pH}$ requirements is mostly focussed on the negative effects a decrease in minimum $\mathrm{pH}$ will have on $P$. miliaris, while there is a possibility that the maximum $\mathrm{pH}$ requirement would actually benefit from a decrease in $\mathrm{pH}$. Predation is quite well researched for sea urchins (Figure 4A), but little is known regarding predation on $P$. miliaris. The juvenile and metamorphosis life stages gain the least attention in sea urchin and $P$. miliaris related research (Figure 4C,D). This could indicate these stages require more attention in habitat requirement related research.

The $P$. miliaris habitat requirements of each of its life stages and the relevant natural factors in the study area were identified as far as information was available. Unfortunately a big portion of the habitat requirements per life stage was not available (Table 2). Nonetheless, this did reveal some significant knowledge gaps. And for more than half of the considered habitat requirements, it was possible to conclude with fair amount of certainty whether they are limiting factors or have minor to no found between winter water temperatures and P. miliaris observations in the Eastern Scheldt and Grevelingen.

Through this detailed case study of the echinoid Psammechinus miliaris, the methods of this complete life cycle approach on habitat requirements was presented. Weak points of the approach are that small trends are hard to pick up and it requires both an extensively researched organism and study area to be able to draw reliable conclusions. Also, it does not take into account the differences in habitat requirements within a species and the interaction effects between (a)biotic factors.

However, strong points include that it is a relatively easy way to get a broad understanding of the habitat requirements of an organism, to identify knowledge gaps in the research area and to prioritise further research efforts. Furthermore, it was able to identify for more than half of the discussed (a)biotic factors whether they were limiting factors or had only 
minor importance. In this way, we will be able to evaluate the importance of a range of (a)biotic factors in determining a species' abundance and distribution and are a step further in understanding the drivers of population fluctuations in nature.

\section{Conclusions and recommendations}

In summary, I distinguish three groups of (a)biotic factors to answer which $P$. miliaris habitat requirements are most likely to be limiting factors in the Eastern Scheldt, Grevelingen and the North sea. Limiting factors that are very likely to be limiting factors to $P$. miliaris. Debatable factors, that require more research to be able to say for certain how important they are to $P$. miliaris abundance and distribution. And Minor- no importance, abiotic factors that are very likely to barely affect $P$. miliaris abundance and distribution (Table 3 ).
This study revealed that hydrodynamics are likely to be an important limiting factor to $P$. miliaris adult abundance and distribution. However, it has received very little research attention (Figure 4AB). I would therefore suggest an experimental study on the effects of different flow speeds on all different sea urchin life stages. Including gamete fertilization success, embryo and larval survival and development, larval settlement and recruitment success and finally the ability of adults and juveniles to remain attached to the substratum.

Bottom type was also found to be an important limiting factor to $P$. miliaris abundance and distribution. Bottom type has also received very little research attention (Figure 4AB). I would therefore suggest an observational study that relates $P$. miliaris presence/absence to the substratum or bottom type of the research area.

Table 3; importance of habitat requirements according to conclusions

\begin{tabular}{lll}
\hline Limiting factors & Debatable factors & Minor- no importance \\
\hline Hydrodynamics & $\mathrm{pH}$ & Hydrostatic pressure \\
Temperature & Predation & Salinity \\
Bottom type & Food availability & \\
& Oxygen & \\
\hline
\end{tabular}

The approach may be improved by including a means of statistically comparing the range of habitat requirements to the range in natural values to be able to give some statistical value to the importance of the discussed habitat requirements. This would make the results more reproducible and comparable.

As a big portion of the information on $P$. miliaris habitat requirements was not available, it would be interesting to see this approach applied to a more extensively studied sea urchin, like Strongylocentrotus purpuratus, to see what conclusions can be drawn. This would allow a comparison between the different life stages to determine which of the life stages is most vulnerable to changes in (a)biotic factors. It also allows an interesting comparison to see both the differences and similarities between two different species of sea urchin. 


\section{Acknowledgements}

Data on the encounter rate of Psammechinus miliaris in the Eastern Scheldt and Grevelingen was supplied by stichting ANEMOON, and the many recreational divers that have sent in their observations. The water temperature data was made available by Rijkswaterstaat. And I would like to thank my supervisor Mischa Streekstra, for her support and feedback. Also thanks to Adriaan Gmelig Meyling for his advice on the statistical analysis.

\section{References}

1. Ellison AM. Mangrove restoration: Do we know enough? Restor Ecol. 2000;8(3):219-29.

2. Rosenfeld J. Assessing the Habitat Requirements of Stream Fishes: An Overview and Evaluation of Different Approaches. Trans Am Fish Soc. 2003;132(December 2012):953-68.

3. Waldbusser GG, Salisbury JE. Ocean acidification in the coastal zone from an organism's perspective: multiple system parameters, frequency domains, and habitats. Ann Rev Mar Sci [Internet]. 2014;6:221-47. Available from: http://www.ncbi.nlm.nih.gov/pubmed/23 987912

4. Johnson ZI, Wheeler BJ, Blinebry SK, Carlson CM, Ward CS, Hunt DE. Dramatic variability of the carbonate system at a temperate coastal ocean site (Beaufort, North Carolina, USA) is regulated by physical and biogeochemical processes on multiple timescales. PLoS One. 2013;8(12):1-8.

5. Carton JA, Seidel HF, Giese BS. Detecting historical ocean climate variability. J Geophys Res Ocean. 2012;117(2):1-18.

6. Mackey B, Lindenmayer D. Fossil fuels future. Science (80- ) [Internet]. 2014 Aug 14;345(6198):739 LP-740. Available from: http://science.sciencemag.org/content/3 45/6198/739.4.abstract

7. Caldeira K, Wickett ME. Oceanography: anthropogenic carbon and ocean $\mathrm{pH}$. Nature. 2003;425(6956):365.

8. Macías-Zamora JV. Chapter 19 Ocean Pollution. In: Waste. 2011. p. 265-79.

9. Watling L, Norse EA. Disturbance of the
Seabed by Mobile Fishing Gear: A Comparison to Forest Clearcutting. Conserv Biol [Internet]. 1998 Dec [cited 2017 May 20];12(6):1180-97. Available from:

http://doi.wiley.com/10.1046/j.15231739.1998.0120061180.x

10. Hamdoun A, Epel D. Embryo stability and vulnerability in an always changing world. Proc Natl Acad Sci [Internet]. 2007;104(6):1745-50. Available from: http://www.pnas.org/cgi/doi/10.1073/pn as.0610108104

11. Dupont S, Dorey N, Stumpp M, Melzner F, Thorndyke M. Long-term and translife-cycle effects of exposure to ocean acidification in the green sea urchin Strongylocentrotus droebachiensis. Mar Biol. 2013;160(8):1835-43.

12. Hughes AD. The Role of Sea Urchin Grazing in Structuring Benthic Communities of Scottish Sea Loch. University of the Highlands and Islands and the Scottish Association for Marine Science, Oban. 2006.

13. Kelly MS, Hughes AD, Cook EJ. Psammechinus miliaris. Dev Aquac Fish Sci. 2013;

14. Otero-Villanueva MDM, Kelly MS Burnell G. How diet influences energy partitioning in the regular echinoid Psammechinus miliaris; constructing an energy budget. J Exp Mar Bio Ecol. 2004;

15. Kalam Azad A, Mckinley S, Pearce CM Factors influencing the growth and survival of larval and juvenile echinoids. Rev Aquac. 2010;2(3):121-37.

16. Kelly MS. Survivorship and growth rates of hatchery-reared sea urchins. Aquac Int. 2002;10(4):309-16.

17. Kelly MS. The reproductive cycle of the sea urchin Psammechinus miliaris (Echinodermata: Echinoidea) in a Scottish sea loch. J Mar Biol Assoc UK. 2000;80(5):909-19.

18. Kelly MS, Cook EJ. The ecology of Psammechinus miliaris. Dev Aquac Fish Sci. 2001;32(C):217-24.

19. Suckling $C C$, Clark MS, Beveridge $C$, Brunner L, Hughes AD, Harper EM, et al. Experimental influence of $\mathrm{pH}$ on the early life-stages of sea urchins I: different rates of introduction give rise to different responses. Invertebr Reprod Dev [Internet]. 2014;58(2):148-59. Available from: http://www.tandfonline.com/doi/abs/10. 1080/07924259.2013.875951

20. Wolff WJ. The echinodermata of the 
estuarine regions of the rivers Rhine, Meuse, and Scheldt, with a list of species occuring in the coastal waters of the Netherlands. Netherlands J Sea Res. 1968;4(1):59-85.

21. A.W. Gmelig Meyling, I. van Lente NS, Bruyne AG\& RH de. Het Duiken Gebruiken 3: Gegevensanalyse van het Monitoringproject Onderwater Oever (MOO). 2013;

22. Aquino-Souza R, Hawkins SJ, Tyler PA. Early development and larval survival of Psammechinus miliaris under deep-sea temperature and pressure conditions. 2008

May;88(3):453-61.

23. Freeman SM, Rogers SI. A new analytical approach to the characterisation of macro-epibenthic habitats: Linking species to the environment. Estuar Coast Shelf Sci. 2003;

24. J. I. Spicer. Oxygen and acid-base status of the sea urchin Psammechinus miliaris during environmental hypoxia. Mar Biol. 1995;124:71-6.

25. Lindahl E, Runnström J. Variation und ökologie von Psammechinus miliaris (Gmelin). Acta Zool. 1929;10(3):40184.

26. Kelly MS, Hunter AJ, Scholfield CL, McKenzie JD. Morphology and survivorship of larval Psammechinus miliaris (Gmelin) (Echinodermata: Echinoidea) in response to varying food quantity and quality. Aquaculture. 2000;183(3-4):223-40.

27. Suckling CC, Clark MS, Beveridge $C$, Brunner L, Hughes AD, Harper EM, et al. Experimental influence of $\mathrm{pH}$ on the early life-stages of sea urchins II: increasing parental exposure times gives rise to different responses. Invertebr Reprod Dev [Internet]. 2014;58(3):161-75. Available from: http://www.tandfonline.com/doi/abs/10. 1080/07924259.2013.875951

28. Meyling, Adriaan Gmelig, Schrieken, Niels, Gittenberger A. Anemoon \&gt; Projecten \&gt; Onderwater (MOO, BES) \&gt; Nederland (MOO) [Internet]. 2016 [cited 2016 Nov 17]. Available from: http://www.anemoon.org/projecten/ond erwater-moo-bes/nederland-moo

29. Rijkswaterstaat. Measurement points [Internet]. [cited 2017 Jan 29]. Available from:

https://waterberichtgeving.rws.nl/nl/wat er-en-weer_dataleveringen_ophalenopgetreden-data.htm?actie=kaart
30. Kelly MS. Environmental parameters controlling gametogenesis in the echinoid Psammechinus miliaris. J Exp Mar Bio Ecol. 2001;266(1):67-80.

31. MarLIN - The Marine Life Information Network - [Internet]. [cited 2017 Feb 15]. Available from:

http://www.marlin.ac.uk/species/detail/1 189

32. Hinegardner RT. Growth and Development of the Laboratory Cultured Sea Urchin. Biol Bull [Internet]. 1969;137(3):465-75. Available from: http://www.jstor.org/stable/1540168

33. Leighton P. Contributions towards the development of echinoculture in North Atlantic waters with particular reference to Paracentrotus lividus (Lamarck). Natl Univ Ireland, Galw. 1995;285.

34. Elmhirst R. Notes on the breeding and growth of marine animals in the Clyde sea area. Rep Scott, mar biol Ass. 1922;1922:13-9.

35. Brattström H. Studien über die Echinodermen des Gebietes zwischen Skagerrak und Ostsee: besonders des Oresundes, mit einer Übersicht über die physische Geographie, von Hand Brattström.[Akademische Abhandlung der philosophischen Fakultät zu Lund. CWK Gleerup ( $\mathrm{H}$. Ohlssons boktryck.); 1941.

36. Kelly MS, Brodie CC, Mckenzie JD. Somatic and gonadal growth of the sea urchin Psammechinus miliaris (Gmelin) maintained in polyculture with the atlantic salmon. J Shellfish Res [Internet]. 1998;17(5):1557-62.

Available from:

https://www.scopus.com/inward/record. uri?eid=2-s2.0-

$0032427305 \&$ partner ID $=40 \& \mathrm{md} 5=04 \mathrm{~d} 5$ 96de5e69cfdeb0ad102067e8caee

37. Gage JD. Skeletal growth zones as age-markers in the sea urchin Psammechinus miliaris. Mar Biol. 1991;110(2):217-28.

38. Jensen M. Breeding and growth of Psammechinus miliaris (Gmelin). Ophelia. 1969;7(November):65-78.

39. Allain JY. Age et croissance de Paracentrotus lividus (Lamarck) et de Psammechinus miliaris (Gmelin) des cotes nord de Bretagne. 1978;122:193204.

40. Engel $\mathrm{H}$. Fauna van Nederland: Echinodermata $(H)$. VI. Leiden: Sijthoff; 1932. (Fauna van Nederland).

41. Mortensen T. A Monograph of the echinoidea| III. 3: camarodonta. II. 
echinidae, strongylocentrotidae, parasaleniidae, echinometridae| text. CA Reitzel; 1943.

42. McEdward LR, Miner BG. Echinoid larval ecology. Dev Aquac Fish Sci. 2001;32(C):59-78.

43. Widdicombe S, Spicer JI. Predicting the impact of ocean acidification on benthic biodiversity: What can animal physiology tell us? J Exp Mar Bio Ecol. 2008;

44. HANCOCK DA. THE FEEDING BEHAVIOUR OF THE SEA URCHIN PSAMMECHINUS MILIARIS (GMELIN) IN THE LABORATORY. Proc Zool Soc London [Internet]. 2009 Aug 20 [cited 2017 Mar 27];129(2):255-62. Available from:

http://doi.wiley.com/10.1111/j.10963642.1957.tb00288.x

45. Jacquin AG, Donval A, Guillou J, Leyzour S, Deslandes E, Guillou M. The reproductive response of the sea urchins Paracentrotus lividus (G.) and Psammechinus miliaris (L.) to a hyperproteinated macrophytic diet. J Exp Mar Bio Ecol. 2006;339(1):43-54.

46. Liu H, Kelly MS, Cook EJ, Black K, Orr $\mathrm{H}$, Zhu JX, et al. The effect of diet type on growth and fatty acid composition of the sea urchin larvae, II.

Psammechinus miliaris (Gmelin). Aquaculture. 2007;264(1-4):263-78.

47. B.A. BANNINK, J.H.M. VAN DER MEULEN RN. Lake Grevelingen: From an estuary to a saline lake. An introduction. Netherlands J Sea Res. 1984;18(267):179-90.

48. Didderen K, Lengkeek W, Bouma S. De verspreiding van witte bacteriematten en schade aan het bodemleven in het Grevelingenmeer III; Onderzoek naar effecten van zuurstofloosheid, zomer 2013 K. 2013;1-52.

49. Caldwell GS, Fitzer S, Gillespie CS, Pickavance G, Turnbull E, Bentley MG. Ocean acidification takes sperm back in time. Invertebr Reprod Dev [Internet]. 2011;55(4):217-21. Available from: http://www.tandfonline.com/doi/abs/10. 1080/07924259.2011.574842

50. Miles H, Widdicombe S, Spicer JI, HallSpencer J. Effects of anthropogenic seawater acidification on acid-base balance in the sea urchin Psammechinus miliaris. Mar Pollut Bull. 2007;

51. Gezelius G. Adaptation of the sea urchin Psammechinus miliaris to different salinities. Zool Bidr Upps.
1963;35:329-37.

52. Ursin E. A quantitative investigation of the echinoderm fauna of the central North Sea. 1960.

53. Cook EJ. Psammechinus miliaris (Gmelin) (Echinodermata: Echinoidea) : factors affecting its somatic growth and gonadal growth and development, and its suitability as a species for sea urchin cultivation [Internet]. Napier University; 1999. Available from:

http://ethos.bl.uk/ProcessSearch.do?qu ery $=410982$

54. Elgershuizen JHBW. Some environmental impacts of a storm surge barrier. Mar Pollut Bull.

1981;12(8):265-71.

55. Kelderman $\mathrm{P}$, Nieuwenhuize $\mathrm{J}$, Meerman-van de Repe AM, Van Liere JM. Changes of sediment distribution patterns in Lake Grevelingen, an enclosed estuary in the SW Netherlands. Netherlands J Sea Res. 1984;18(3-4):273-85.

56. Jennings S, Lancaster J, Woolmer A, Cotter J. Distribution, diversity and abundance of epibenthic fauna in the North Sea. J Mar Biol Assoc UK. 1999;79(1999):385-99.

57. Duineveld GCA, Künitzer A, Niermann U, De Wilde PAWJ, Gray JS. The macrobenthos of the north sea. Netherlands J Sea Res. 1991;28(12):53-65.

58. Coolen JWP, Bos OG, Glorius S, Lengkeek W, Cuperus J, van der Weide $B$, et al. Reefs, sand and reef-like sand: A comparison of the benthic biodiversity of habitats in the Dutch Borkum Reef Grounds. J Sea Res [Internet]. 2015;103:84-92. Available from: http://dx.doi.org/10.1016/j.seares.2015. 06.010

59. Havermans C, De Broyer C, Mallefet J, Zintzen V. Dispersal mechanisms in amphipods: A case study of Jassa herdmani (Crustacea, Amphipoda) in the North Sea. Mar Biol. 2007;153(1):83-9.

60. Rumrill SS. Natural mortality of marine invertebrate larvae. Ophelia [Internet]. 1990;32(1-2):163-98. Available from: http://www.tandfonline.com/doi/abs/10. 1080/00785236.1990.10422030

61. Thorson G. Reproductive and larval ecology of marine bottom invertebrates. Biol Rev. 1950;25(1):1-45.

62. Lamare MD, Barker MF. In situ estimates of larval development and mortality in the New Zealand sea urchin 
Evechinus chloroticus (Echinodermata: Echinoidea). Mar Ecol Prog Ser. 1999;180:197-211.

63. Freire J, Gonzalez Gurriaran E. Feeding ecology of the velvet swimming crab Necora puber in mussel raft areas of the Ria de Arousa (Galicia, NW Spain). Mar Ecol Prog Ser. 1995;119(1-3):139-54.

64. Brun E. Food and feeding habits of luidia ciliaris echinodermata:

Asteroidea. J Mar Biol Assoc United Kingdom [Internet]. 1972;52(1):225-36. Available from:

https://www.scopus.com/inward/record. uri?eid=2-s2.0-

$84971958023 \&$ doi $=10.1017 \% 2 F S 0025$

$315400018671 \&$ partner $I D=40 \& m d 5=e 6$

2e9ce1506e7c2154b7edb646860568

65. Adema J, den Hartog JC. De krabben van Nederland en België (Crustacea, Decapoda, Brachyura). Nationaal Natuurhistorisch Museum Leiden; 1991.

66. Avant P. Luidia ciliaris Seven-armed starfish. In Tyler-Walters $\mathrm{H}$. and Hiscock K. (eds) Marine Life Information Network: Biology and Sensitivity Key Information Reviews [Internet]. Plymouth: Marine Biological Association of the United Kingdom. 2008 [cited 2017 Apr 2]. Available from: http://www.marlin.ac.uk/species/detail/1 757

67. Fenaux L, Strathmann M, Strathmann R. Five tests of food-limited growth of larvae in coastal waters by comparisons of rates of development and form of echinoplutei. Limnol Oceanogr. 1994;39(1):84-98.

68. Paulay G, Boring L, Strathmann RR. Food limited growth and development of larvae: Experiments with natural sea water. J Exp Mar Bio Ecol. 1985;93(12):1-10.

69. Lawrence JM. On the relationships between marine plants and sea urchins. 1975;

70. Anselmo HMR. Effects of Marine Persistent Organic Pollutants on Early Life Development and Metamorphosis of Echinoids. 2012. 161 p.

71. Byrne M, Przeslawski R. Integrative and Comparative Biology Multistressor Impacts of Warming and Acidification of the Ocean on Marine Invertebrates ' Life Histories. 2013;53(4):582-96.

72. Dupont $\mathrm{S}$, Ortega-Martínez $\mathrm{O}$, Thorndyke M. Impact of near-future ocean acidification on echinoderms. Ecotoxicology. 2010;19(3):449-62.
73. Natuur- en Recreatieschap

Zuidwestelijke Delta p/a

Staatsbosbeheer. Technical data

Grevelingen lake [Internet]. [cited 2017

Feb 1]. Available from:

http://www.grevelingen.nl/content.asp?

menu $=1$ \&submenu $=3 \&$ page $=339$ \&lang

$$
=1
$$

74. Sw T, Sea N. Lake Grevelingen: a case study of ecosystem changes in a closed estuary. 1978;(175):246-59.

75. Hoeksema HJ. Grevelingenmeer van kwetsbaar naar weerbaar? 2002;

76. Rob Nieuwkamer, Lennart Turlings, Jan-Willem Slager PP. Verkenning "Grevelingen water en getij." Deltares Rap Z4576. 2009;27-30.

77. Zuijdgeest A. Carbon cycling and its effect on oxygen concentrations and $\mathrm{pH}$ in a seasonally anoxic coastal marine system. 2012;

78. Paramor OAL, Allen KA, Aanesen M, Armstrong C, Hegland T, Le Quesne W, et al. North Sea Atlas. 2009;(August):80.

79. DECC. Future Leasing for Offshore Wind Farms and Licensing for Offshore Oil \& Gas and Gas Storage Environmental Report. UK Offshore Energy Strateg Environ Assess Environ Rep [Internet]. 2009;(January):343-74. Available from:

https://www.gov.uk/government/publicat ions/uk-offshore-energy-strategicenvironmental-assessment-oeseaenvironmental-report

80. Provoost $\mathrm{P}$, Van Heuven $\mathrm{S}$, Soetaert $\mathrm{K}$, Laane RWPM, Middelburg JJ.

Seasonal and long-term changes in $\mathrm{pH}$ in the Dutch coastal zone.

Biogeosciences. 2010;7(11):3869-78.

81. Heath MR. High salinity in the North Sea. Nature. 1991;352(6331):116.

82. Meteoblue. Climate North Sea meteoblue [Internet]. [cited 2017 Mar 11]. Available from:

https://www.meteoblue.com/en/weather /forecast/modelclimate/north-

sea_united-states-of-america_5129210

83. Rijkswaterstaat. Oosterschelde |

Rijkswaterstaat [Internet]. [cited 2017

Mar 27]. Available from:

http://www.rijkswaterstaat.nl/water/vaar wegenoverzicht/oosterschelde/index.as px

84. Nationaal Park Oosterschelde [Internet]. [cited 2017 Mar 27]. Available from: http://www.np-oosterschelde.nl/

85. HP33 Getijden en stroomatlas. Royal Dutch Navy, Hydrographical Survey; 
2012. 268-293 p.

86. Richard Dame, Norbert Dankers, Theo Prins, Henk Jongsma AS. The Influence of Mussel Beds on Nutrients in the Western Wadden Sea and Eastern Scheldt Estuaries. Coast
Estuar Res Fed. 2017;14(2):130-8.

87. Google Maps [Internet]. 2016. Available from:

https://www.google.nl/maps/@51.62405 $53,4.0243868,48230 \mathrm{~m} / \mathrm{data}=! 3 \mathrm{~m} 1 ! 1 \mathrm{e} 3$ 


\section{Appendix}

Table 4. Natural values of abiotic factors in the Grevelingen lake.

\begin{tabular}{lllll}
\hline Abiotic factor & Minimum & Average & Maximum & References \\
\hline Depth $(\mathrm{m})$ & 0 & 5.3 & 48 & $(73)$ \\
Hydrodynamics $(\mathrm{m} / \mathrm{s})$ & 0 & $<0.1$ & 0.1 & $(74)$ \\
Oxygen $\left(\mathrm{mg} \mathrm{O}_{2} / \mathrm{L}\right)$ & $<2$ & - & 18 & $(47,75,76)$ \\
$\mathrm{pH}$ & 7 & 8 & 9 & $(77)$ \\
Pressure $(\mathrm{atm})$ & 1 & 1.53 & 5.8 & Calculated from depth \\
Salinity $(\mathrm{g} \mathrm{Cl} / \mathrm{L})$ & 28 & & 34 & $(77)$ \\
Watertemperature $\left({ }^{\circ} \mathrm{C}\right)$ & 0.1 & 12 & 25.5 & Own data \\
\hline
\end{tabular}

Table 5. Natural values of abiotic factors in the North Sea.

\begin{tabular}{lllll}
\hline Abiotic factor & Minimum & Average & Maximum & References \\
\hline Depth $(\mathrm{m})$ & 0 & 90 & 700 & $(78)$ \\
Hydrodynamics $(\mathrm{m} / \mathrm{s})$ & 0.25 & 0.5 & 2.5 & $(79)$ \\
Oxygen $(\mathrm{mg} \mathrm{O} / \mathrm{ml})$ & - & - & - & \\
$\mathrm{PH}$ & 7.7 & 8.1 & 8.6 & $(80)$ \\
Pressure $(\mathrm{atm})$ & 1 & 10 & 71 & Calculated from Depth \\
Salinity $(\mathrm{ppt})$ & 33.5 & 35 & 35.45 & $(81)$ \\
Temperature $\left({ }^{\circ} \mathrm{C}\right)$ & -5 & 12 & 27 & $(82)$ \\
\hline
\end{tabular}

Table 6. Natural values of abiotic factors in the Eastern Scheldt

\begin{tabular}{lllll}
\hline Abiotic factor & Minimum & Average & Maximum & References \\
\hline Depth $(\mathrm{m})$ & 0 & 9 & 48.8 & $(83,84)$ \\
Hydrodynamics $(\mathrm{m} / \mathrm{s})$ & 0 & 0.45 & 1.65 & $(85)$ \\
Oxygen $\left(\mathrm{mg} \mathrm{O}_{2} / \mathrm{L}\right)$ & - & - & - & \\
$\mathrm{PH}$ & 7.5 & 7.9 & 8.3 & $(80)$ \\
Pressure $(\mathrm{atm})$ & 1 & 1.9 & 5.2 & Calculated from depth \\
Salinity $(\mathrm{ppt})$ & 30 & & 33 & $(86)$ \\
Temperature $\left({ }^{\circ} \mathrm{C}\right)$ & -0.1 & 11.5 & 24 & Own data \\
\hline
\end{tabular}

Table 7. Psammechinus miliaris (measurable) habitat requirements

\begin{tabular}{lllllll}
\hline (A)biotic factors & Life stages & minimum & optimum & maximum & Location & References \\
\hline Food quantity $(\mathrm{cells} / \mathrm{ml})$ & $\mathrm{L}$ & 500 & $1500-4000$ & $>4000$ & Scotland (UK) & $(26)$ \\
Hydrodynamics $(\mathrm{m} / \mathrm{s})$ & $\mathrm{A}$ & & & $>0.4$ & English channel & $(23)$ \\
Oxygen $(\mathrm{mg} \mathrm{O} / \mathrm{ml})$ & - & - & - & - & - & - \\
$\mathrm{pH}$ & $\mathrm{A}, \mathrm{G}$ & $6.16(\mathrm{~A})$ & $7.95(\mathrm{G})$ & - & Plymouth $(\mathrm{UK})$ & $(49,50)$ \\
Pressure $(\mathrm{atm})$ & $\mathrm{E}, \mathrm{L}$ & 1 & - & $100(\mathrm{E}),>200(\mathrm{~L})$ & Plymouth $(\mathrm{UK})$ & $(22)$ \\
Salinity $(\mathrm{ppt})$ & $\mathrm{A}, \mathrm{G}, \mathrm{E}$ & $<14.8(\mathrm{~A}), 20-26(\mathrm{G}, \mathrm{E})$ & - & $32-38(\mathrm{G}, \mathrm{E})$ & former Zuiderzee $(\mathrm{NL})$ & $(40,51)$ \\
Temperature $\left({ }^{\circ} \mathrm{C}\right)$ & $\mathrm{E}, \mathrm{L}$ & $5(\mathrm{E}),<5(\mathrm{~L})$ & & - & Plymouth $(\mathrm{UK})$ & $(22)$ \\
\hline
\end{tabular}

